\title{
SEWAGE SLUDGE TREATMENT FOR FERTILIZER PRODUCTION USING BIOTECHNOLOGIES: PERSPECTIVES FOR THE BEZLUDIVKA WASTEWATER TREATMENT PLANT, KHARKIV
}

\author{
Lidija Svirenko ${ }^{I}$ \\ Natasha Suchkova ${ }^{2}$ \\ 'Kharkiv National Academy of Municipal Economy, Ukraine \\ ${ }^{2}$ Kharkiv Wastewater Management Company, Ukraine
}

\begin{abstract}
Complex "Dikanivka" \& "Bezludivka" wastewater treatment plant (WWTP, Kharkiv) is one of the biggest in Ukraine. Mixture of industrial and domestic wastewater is treated on the station. Great volume of sewage sludge has been produced and accumulated for forty years of the plant operation. Environment of the region has been affected rather seriously in result of out-of-date sludge dewatering system exploitation and heaps of dewatered sludge on the territory of the plant. Environment stabilization in the area of sludge treatment is an urgent problem of the region. Phytoremediation as a promising natural technology for the purpose is discussed in the article.
\end{abstract}

Sewage sludge is rich in organic matter and nutrient elements (nitrogen and phosphates) therefore it could be applied for soil fertilization. On the other hand, due to high heavy metals $(\mathrm{Cd}, \mathrm{Ni}, \mathrm{Cu}, \mathrm{Cr})$ concentration in sludge, contamination with enteric parasites, $\mathrm{pH}$ less than 5,5 there is restriction for sludge application in agricultural production.

Willow (Salix spp.) is discussed as a plant for phytoremediation of the territory and for substratum properties melioration because of its availability to accumulate heavy metals, regulate concentration of nutrients, high biomass production and high environmental tolerance.

Experiment in situ has to be carried for the plant-remediater selection and for investigation of sludge agricultural properties dynamic.

\section{KEYWORDS}

Agricultural properties; Biomass; Contamination; Dewatering; Environmental management; Fertilizer; Melioration; Metal up-taking; Phytoremediation; Salix; Sewage sludge; Willow 


\section{INTRODUCTION}

Kharkiv (1.5 million inhabitants) is the city located on a rolling plain in the Forest-Steppe zone in the North-Eastern Ukraine with developed industrial, scientific and cultural sectors. Mixed municipal and industrial wastewater is treated on the "Dikanivka" \& "Bezludivka" wastewater treatment plants. Further treatment of the sludge generated on the both WWTP is effected on the "Bezludivka" plant. Annual volume of sludge to be treated is more one million cubic meters. Great volume of sewage sludge has been produced and accumulated for forty years of the plant operation. Environment of the region has been affected rather seriously in result of out-of-date sludge dewatering system exploitation and heaps of dewatered sludge on the territory of the plant.

The"Bezludivka" WWTP is situated near the southern border of the city of Kharkiv, elevation is $80-220 \mathrm{~m}$. All territory of the plant is approximately $256 \mathrm{ha}$, and $126 \mathrm{ha}$ of them are occupied with sewage sludge dewatering ponds and dewatered sludge storage yard.

Ponds for sludge dewatering have been constructed without impervious curtain, drainage system and with surface removal of separated water. Separated water and leachate from ponds have cause for shallow water pollution. Mechanical system of sewage sludge dewatering with centrifuges "Westfalia-Separator" has been included in operation on the "Bezludivka" WWTP since 2004. None the less traditional dewatering system using ponds is partly working too.

Dewatered sludge is stored on the yard near these ponds and for today a huge volume of sewage sludge has been accumulated Sewage sludge is rich in organic matter and nutrient elements (nitrogen and phosphates); therefore it could be applied for soil fertilization. But according to Ukrainian regulations, there is restriction for sludge application in agricultural production for its contamination with heavy metals, organic pollutants and enteric parasites. So sludge utilization is one of the complicated problems for the "Bezludivka" WWTP.

Dried sludge dispersed by wind can affect neighboring agriculture land and sites for recreation in the valley of the Udy River. Oil products contained in sewage sludge are caused numerous fires on the territory with emission of combustion products to the atmosphere. Besides these sites produce some "visual intrusion" to the society, first of all to inhabitants of little villages situated near the "Bezludivka" WWTP.

Taking into account said above the set of environmental problem has to be solved on the "Bezludivka" WWTP. Main tasks are surface of dewatered sludge stabilization, prevention of shallow water pollution and dewatered sewage sludge melioration for applying it in agriculture as fertilizer. To keep in mind economic aspects of dewatered sewage sludge management phytotechnologies are proposed. Backgrounds for willow (Salix spp.) applying as a plant for phytoremediation are discussed in the report [7].

\section{METHODS OF SLUDGE INVESTIGATION}

Pilot studies was carried out in the summer of 1998 and in the autumn of 2004 with sampling and studying physical, chemical and biological properties of dewatered sewage sludge to estimate the material as a potential fertilizer according regulation [2, 3]. In 1998 sludge was analyzed on heavy metals contents and sanitary micro bacteriological properties; in $2004-$ agrochemical properties and metal content. 


\subsection{Field sampling}

Samples were taken according to actual Ukrainian regulation [2, 3]. For sampling the territory of sewage sludge storage was divided on two sites. At every site ten plots were randomly selected, each with in area of approximately $25 \mathrm{~m}^{2}$. Samples in the frame of a plot were collected from two levels: $0-5 \mathrm{~cm}$ and $5-20 \mathrm{~cm}$. The results presented in the paper are based on the average mean of concentration obtained for ten plots of every site.

\subsection{Samples treatment}

In order of preparation samples of sludge were oven-dried and analyzed regarding agricultural properties, such as $\mathrm{pH}$, humidity, contents of organic matter, nutrients (nitrogen and phosphate), and sanitary micro bacteriological properties. General nitrogen content was determined according to Kjeldal's method, general phosphorus content - for Ginsburg's method (colourimetrical method application to the sludge samples previously ashed in the mixture of $\mathrm{HCl}$ and $\mathrm{H}_{2} \mathrm{SO}_{4}$ ).

Metals content determination was processed applying atom-absorption, atomic emission and radioanetric roentgen-fluorescent analyses. Samples for the analyses were ignited at the temperature up to $5000{ }^{\circ} \mathrm{C}$. The range of elements determined includes cadmium, cobalt, copper, nickel, manganese, lead, strontium, chromium, zinc, iron, silver, selenium.

\subsection{Results of analyses}

As to agricultural properties of the sludge correlation between nutrients content is disturbed. Organic matter content is some lower than permissible minimum and $\mathrm{pH}$ meaning has to be higher (Table 1).

Table1. Agricultural properties of the sewage sludge

\begin{tabular}{lccc}
\hline Index & \multicolumn{2}{c}{$\begin{array}{c}\text { Index concentration in the sewage } \\
\text { sludge }\end{array}$} & $\begin{array}{c}\text { Permissible limits, } \\
\mathrm{mg} / \mathrm{kg} \text { according to } \\
\text { Standard of Russia [3] }\end{array}$ \\
\cline { 2 - 4 } & Site I & Site II & 20 \\
Organic matter, \% in DM & 14,4 & 5,3 & $5.5-8.5$ \\
$\mathrm{pH}$ & 5,3 & 2,8 & 0.6 \\
General nitrogen, \% & 3,3 & 3,6 & 1.5 \\
General phosphorus $\left(\mathrm{P}_{2} \mathrm{O}_{5}\right), \%$ & 3,5 & 0,28 & - \\
General potassium, \% & 0,39 & 28,3 & $20-80$ \\
Humidity, \% & 28,3 & & \\
\hline
\end{tabular}

The heavy metals content in sewage sludge (DM) is presented in Table 2. For some metals level of concentration in sewage sludge is essentially higher than background concentration in soil of the region. For lead coefficient of concentration equals 8-12; for cadmium 10-16; for zinc 12-14; for chromium 10-30; for copper 20-40; and for silver it reaches 100 and more. 
Table2. Metals content in dry matter (DM) of sludge (after Bolshakova, [16]).

\begin{tabular}{|c|c|c|c|c|c|}
\hline \multirow[t]{2}{*}{ Metals } & \multicolumn{2}{|c|}{$\begin{array}{c}\text { Metals content in } \\
\text { sludge, } \mathrm{mg} / \mathrm{kg} \mathrm{DM}\end{array}$} & \multirow{2}{*}{$\begin{array}{l}\text { Background concentration } \\
\text { in the soils of Kharkiv } \\
\text { region, } \mathrm{mg} / \mathrm{kg}[11]\end{array}$} & \multicolumn{2}{|c|}{$\begin{array}{l}\text { Permissible limits, } \mathrm{mg} / \mathrm{kg} \text {, } \\
\text { according to Standards }\end{array}$} \\
\hline & Site I & Site II & & Ukraine [2] & Russia [3] \\
\hline $\mathrm{Cd}$ & 8.83 & 6.44 & 0,5 & 30 & 15 \\
\hline Co & - & - & 11,0 & 100 & - \\
\hline $\mathrm{Cu}$ & 1379.2 & 675 & 27,0 & 1500 & 750 \\
\hline $\mathrm{Ni}$ & 294.58 & 160 & 38,0 & 200 & 200 \\
\hline $\mathrm{Mn}$ & 940.83 & 745.3 & 660 & 2000 & - \\
\hline $\mathrm{Pb}$ & 243.83 & 172 & 20,0 & 750 & 250 \\
\hline $\mathrm{Sr}$ & 116.67 & 104.5 & 100 & 400 & - \\
\hline $\mathrm{Cr}$ & 2015 & 708 & 70,0 & 750 & 500 \\
\hline $\mathrm{Zn}$ & 893.33 & 847 & 70,0 & 2500 & 1750 \\
\hline $\mathrm{Fe}$ & 22833.33 & 13500 & 14000 & 25000 & - \\
\hline
\end{tabular}

Table3. Results of sanitary and bacteriological analyses.

\begin{tabular}{cccc}
\hline Index, cells/g & \multicolumn{2}{c}{$\begin{array}{c}\text { Index concentration in the sewage } \\
\text { sludge }\end{array}$} & $\begin{array}{c}\text { Permissible limits, mg/kg } \\
\text { according to Standard of } \\
\text { Russia [3] }\end{array}$ \\
\cline { 2 - 3 } & Site 1 & Site 2 & 100 \\
Escherichia Coli & $3.3 \cdot 10^{6}$ & $5.5 \cdot 10^{3}$ & Doesn't limit \\
Cl. Perfring & $>0.1$ & - & Absence \\
Pathogen microorganisms & - & - & Absence \\
Intestinal worm, piece/kg & - & - & \\
\hline
\end{tabular}

\subsection{Results and discussion}

Thus, according to obtainad results we can make some conclusions:

- agricultural properties of sewage sludge need correction (organic matter content is not enough high; nitrogen content is too much; $\mathrm{pH}$ reaction is light acid);

- metals content is sufficient higher than background concentration and for $\mathrm{Cu}, \mathrm{Ni}, \mathrm{Cr}$ exceeds permissible level;

- data about organic pollutants content in sludge have not been obtained;

- pathogen bacteria (E-Coli) concentration is under the limit.

Methods of melioration have to be applied to the sewage sludge before using the matter as fertilizer. Treatment using chemical methods (e.g. using acid and complexing chemicals) is either costly or impossible for large volume to be treated. The use of plants for melioration, polluted sites stabilization and remediation is a more economic and environmentally friendly alternative. 


\section{PHYTOTECHNOLOGY FOR SLUDGE TREATMENT}

Application of phytotechnologies is proposed on the "Bezludivka" WWTP taking into account urgent need to solve the set of environmental problems discussed above and meliorate sewage sludge for fertilizer.

Plants and microbes play a unique role in organic pollutants degradation and the fate of metals in soils due to ability change their chemical status and state in the soil-plant-wateratmosphere system. For their ability taking some elements up from soils and concentrate high quantities of metals in their upper parts plant species could be divided onto hyperaccumulators, accumulators, indicators and excluders [6].

Plants hyper accumulators and accumulators could be used as tools for phytoremediation of metal contaminated soils and sludge. Plants species hyper accumulators are privileged candidates for large scale phytoremediation, but hyper accumulation is not common: only about 440 plant species with such properties are known now. Some wide spread species accumulators are as follows: Salix caprea, S. fragilis, Betula pendula, Populus nigra, Plantago dindellata, Stanley pinnata, Brassica jucea. [5, 6, 7].

There are some examples of willow application for $\mathrm{Ni}, \mathrm{Cd}, \mathrm{Zn}$ extraction from polluted soils and Brownfield and disturbed soils $[8,10,12,13]$. Community of trees including Salix sp. has been used in large scale for multipurpose soil remediation in Great Britain [9]. Advantages of the willow as a plant remediater is long roots (up to $5 \mathrm{~m}$ ), nitrogen content in soil water regulation, metal taking up with coefficient accumulation in steam and shoots up to ten.

In Ukraine preferences could be made to some Willow (Salix spp.) species because of its wide spread of studied region, high ability to metal up-taking from contaminated sites, huge biomass production and also because it is suitable for different soil structure, mechanical composition, $\mathrm{pH}$ and moisture condition. Also Willow could be suitable to add organic matter into soils due to deciduous of leaves.

\section{CONCLUSIONS}

Based on the studies of sewage sludge treatment system and environmental situation on the "Bezludivka" region the following conclusions could be drawn:

- Sewage sludge treatment system is too dangerous for the environment, it has caused such serious problems as shallow water and groundwater pollution; soil contamination by the toxic elements, air pollution produced by the harmful gases after fires processes, etc. All of them connect with huge amount of sludge accumulated on the station;

- The pilot study of sewage sludge properties shows potential possibility of its use as fertilizers. On the one hand, huge amount of sludge contains organic matter and nutrients. On the other hand, sludge exceeds some indexes according to Regulations of Ukraine and Russia. It is contaminated by the heavy metals, first of all $\mathrm{Ni}, \mathrm{Cr}, \mathrm{Cu}, \mathrm{Zn}$; enteric parasites; contains nitrogen and phosphates in concentrations biggest than it is permitted; has low $\mathrm{pH}$;

- Phytotechnology is proposed as cheaper and environmentally friendly. The Willow (Salix spp.) is considered as a local plant of phytotechnology due to its availability to accumulate heavy metals, regulate concentration of nutrients, high biomass production and high 
environmental tolerance. Also it is necessary to consider a possibility of plant community cultivation, where is Willow will be a main plant;

- Phytoremediation application can caused some positive effiects. In worse case we'll have improvement of environmental situation of the studied region through the reclamation of polluted sites. In best case we'll have organic fertilizers produced from sludge and might be fossil fuel resources. Phytotechnology have also positive effect to social sphere due to green fringe around the grounds ofa“'Bezludivka" WWTP;

- The next stage should be application of some experimental works in situ and study sludge properties with systematic and willow's ability to remove some toxic elements, regulate nutrients contents and $\mathrm{pH}$. Obtained data are necessary for construction of realistic balance model of elements removal from sludge and its carrying out to plant;

- The problem is also utilization the huge biomass production. It is possible incineration of biomass with filters use for harmful gases treatment. But it should be decided before phytotechnology application.

\section{ACKNOWLEDGEMENTS}

The stuff of Chemistry Laboratory of the Scientific and Research Institute of Environmental Problem (Kharkiv, Ukraine) and Chemistry Research Institute of Kharkiv National V. Karazin University are all acknowledged for their support of the research, presented in the paper.

\section{REFERENCES}

[1] Communication from the Commission to the Council, the European parliament, the Economic and Social committee and the Committee of the Regions: Towards a Thematic Strategy for Soil.

[2] TU 204 Ukraini 76-93, 1994. "Dobriva z osadiv stichnix vod" (Standard of Ukraine "Fertilizers are made from sewage sludge"). Kharkiv, Ukraine (in Ukrainian).

[3] GOST R 17.4.3.a7-2001, 2001. Okhrana prirodi. POCHVI. "Trebovaniay k svoystvam osadkov stochnikh vod pri ispolzovanii ikh v kachestve ydobreniy" (Standard of Russia "Requirements to the sewage sludge properties as potential fertilizers") (in Russian).

[4] GOST 17.4.3.05-86 Okhrana prirodi. POCHVI. "Trebovaniay k stochnim vodam i ikh osadkamdlya orosheniay i ydobreniya" (Nature protection. soils. Requirements for wastewater and its sediments for irrigation and fertilization, Standard of Russia) (in Russian).

[5] Phytoremediation of Metal-Contaminated Soils /Proceedings of the NATO Advanced Study Institute: Třešt, Czech Republic, August 2002.

[6] Morel, J.L. 2002. The Aims of the Remediation of Metal-Polluted Soils. Ibid.

[7] Schwartz, Ch., 2002. Behavior of hyper accumulator plants on metal-polluted soils phytoremediation. Ibid.

[8] Keller, C. 2002. Limitations and Technical Implications of Phytoextraction of Metals at Multi-Metals Contaminated Sites. Ibid.

[9] Dickinson, N., 2002. Phytoremediation of Industrial-Contaminated Sites Using Trees. Ibid.

[10] Boruvka, L., 2002. Phytoremediation of Metal-Contaminated Sites in the Litavka Area and in Czech Republic. Ibid. 
[11] Kovalevsky, L., 1991. Biogeochemistry of the Plants. 'Science' Pub 1. House, Novosibirsk (in Russian).

[12] Svirenko, L., Vergeles, Ju., Jakovlev, V., 2003. Metals accumulation in soils and vegetation of river valleys in the city of Kharkiv, Ukraine. In: Abstracts book of the $2 \mathrm{~d}$ international conference "Soils of Urban, Industrial, Traffic and Mining Areas", July 911,aNancy, France, pp. 103-104.

[13] Svirenko, L., Spirin, O., Uvarova, G., 2003. Rol vidov ivy v technologijach vosstanovlenija okruzhayuschey sredy.- Materialy konferencij "Falzfeynovskie chtenija" (Willow species as a tool of environment remediation technologes). In: Proceedings of Cherson conference "Falzfein readings"), April 23-25, Cherson, Ukraine, pp. 315-317 (in Russian);

[14] Shilova , I., 1989. Jestestvennaja rastitel'nost' zavodskich territorij industrial'nogo tsentra (Natural vegetation of works grounds in industrial center). In: Rastenija i promyshlennaja sreda (Plants and industrial environment). UralGU Publ. House, Sverdlovsk (in Russian), pp.44-56.

[15] Korjakovsky, Yu., Nechaev, A.. Biological decontamination of sites affected by chemical and radioactive agents in Russia: an overview/ Proceedings of the NATO Advanced Study Institute: Zhitomir, Ukraine, August 2005.

[16] Fedoseyenko, D. Phytoremediation of petroleum-contaminated soils in the Poltava region (Central Ukraine). Situation analysis and target setting. Ibid.

[17] Bolshakova, E. Metodi udoskonaluvannya sistemi reguluvannya skidy promislovix stichnix vod (The methods of improvement the wastewater treatment system manage), Kharkiv, 2002 (in Russian). 